\title{
PENGARUH MODEL PEMBELAJARAN BERBASIS MASALAH TERHADAP HASIL BELAJAR KOGNITIF SISWA KELAS VII SMP
}

\author{
Insar Damopolii ${ }^{1)}$, Aksamina M. Yohanita ${ }^{1)}$, Febilia H. Malatta' ${ }^{1)}$, Frida M. Yusuf ${ }^{2)}$ \\ ${ }^{1}$ Jurusan Pendidikan Biologi, Universitas Papua, Jl. Gunung Salju, Amban, Manokwari \\ ${ }^{2}$ Jurusan Biologi, Universitas Negeri Gorontalo, Jl. Jendral Sudirman, Gorontalo \\ e-mail: i.damopoli@unipa.ac.id
}

\begin{abstract}
The purpose of research to determine that effect of problem-based learning (PBL) model on cognitive student achievement in SMP YPPGI Silo Manokwari in the relation of population density to the environment topic. The study was a quasi-experimental research used nonequivalent control group design. The sample of the study was the students of class VIIA such as experimental class and the total students as many as 23 students and the class VIIB such as the control class and the total students as many as 22 students. That result showed the experimental class to implementation PBL model obtained the average posttest 70,78, while the class control obtained the average posttest 50,05 . The significant value was $0,01<\alpha=0,05$, there were different cognitive student achievement between the experiment class and the control class. Conclusion, there are differences in cognitive students achievement between students taught using PBL model with students taught using a conventional learning model
\end{abstract}

Keyword: Problem based learning model, Student achievement

Submited

Accepted :

\section{PENDAHULUAN}

Belajar merupakan unsur yang sangat mendasar dalam penyelenggaraan di semua jenjang pendidikan. Keberhasilan pencapaian tujuan pendidikan bergantung pada keberhasilan suatu proses belajar yang dilaksanakan di sekolah dan dukungan lingkungan sekitarnya. Proses belajar dapat terjadi karena interaksi seseorang dengan lingkungannya yang akan menghasilkan suatu perubahan tingkah laku pada berbagai aspek, diantaranya pengetahuan, sikap, dan keterampilan.

Pada kegiatan belajar mengajar di dalam kelas terjadi proses penilaian yang akan menentukan tingkat pengetahuan serta mengukur ketercapaian belajar siswa. Hasil belajar merupakan faktor yang sangat penting, karena hasil belajar yang dicapai siswa merupakan alat untuk mengukur sejauh mana siswa menguasai materi yang diajarkan oleh guru. Terdapat tiga faktor yang mempengaruhi keberhasilan proses dan hasil belajar, yaitu faktor internal (faktor dari dalam individu), faktor eksternal (faktor dari luar individu), dan faktor pendekatan belajar yakni jenis upaya belajar siswa yang meliputi strategi dan metode yang digunakan siswa untuk melakukan kegiatan mempelajari materi-materi pelajaran (Slameto, 2013).

Selain faktor keberhasilan pada proses belajar, yang perlu diperhatikan dalam pendidikan adalah kualitas pembelajaran. Pengembangan kualitas pembelajaran dilakukan untuk mengamati keaktifan siswa dalam proses belajar mengajar dan kualitas 
berhubungan dengan materi yang dipelajari. Pengetahuan dan pemahaman atas materi yang diajarkan masih rendah. Pada pembelajaran dengan menggunakan model pembelajaran konvensional guru lebih banyak mendominasi kegiatan pembelajaran, dimana terbentuk kegiatan pembelajaran yang berpusat pada guru (Munir, Damopolii, \& Iwan, 2018). PBM menjadi pembelajaran yang efisien karena siswa tidak hanya belajar, tetapi juga memperoleh pemahaman yang mendalam (Jansson, Söderström, Andersson, \& Nording, 2015). Pemahaman yang mendalam terhadap materi, membuat siswa ketika diberi posttest dapat menjawab dengan baik dengan persentase pencapaian KKM 60 lebih dari $80 \%$.

Model PBM membuat siswa yang awalnya pasif dalam pembelajaran menjadi siswa yang aktif. Siswa aktif dalam bertanya, berdiskusi, memecahkan masalah, serta menyampaikan ide dan gagasan lebih terbuka. Pemahaman konsep terhadap materi hubungan kepadatan populasi terhadap lingkungan menjadi lebih baik dengan PBM. Pemahaman konsep yang baik meningkatkan pencapaian hasil belajar siswa.

\section{SIMPULAN DAN SARAN}

Kesimpulan dalam penelitian ini adalah terdapat perbedaan hasil belajar kognitif siswa yang diajarkan dengan menggunakan model pembelajaran berbasis masalah (PBM) dengan siswa yang diajarkan dengan menggunakan model pembelajaran konvensional. Siswa dalam pembelajaran menggunakan PBM menjadi lebih aktif, dan mampu memecahkan masalah yang diberikan oleh guru dengan sangat baik.

Pada penelitian selanjutnya agar dapat menggunakan model PBM dengan mengukur hasil belajar lainnya seperti afektif dan psikomotorik. Guru dalam proses belajar mengajar hendaknya menggunakan PBM untuk memperbaiki hasil belajar siswanya.

\section{RUJUKAN}

Argaw, A. S., Haile, B. B., Ayalew, B. T., \& Kuma, S. G. (2017). The Effect of Problem Based Learning (PBL) Instruction on Students' Motivation and Problem Solving Skills of Physics. EURASIA Journal of Mathematics Science and Technology Education, 13(3), 857871.

Ayyildiz, Y., \& Tarhan, L. (2018). Problembased Learning in Teaching Chemistry: Enthalpy Changes in Systems. Research in Science \& Technological Education, 36(1), 3554. doi:10.1080/02635143.2017.136 6898

Baransano, A. Y., Yohanita, A. M., \& Damopolii, I. (2017). Penerapan Model Pembelajaran Picture And Picture untuk Meningkatkan Hasil Belajar Biologi Siswa Kelas XI IPA SMA YABT Manokwari. Seminar Nasional MIPA II Universita Papua "Konservasi, Matematika, Sains dan Teknologi" (hal. 273-280). Jakarta: Sinar Grafika.

Chin, C., \& Chia, L. G. (2004). Implementing Project Work in Biology through Problem-based Learning. Journal of Biological Education, 38(2), 69-75.

Chin, C., \& Chia, L. G. (2006). Problem-based learning: Using ill-structured problems in biology project work. Science Education, 90(1), 44-67.

Damopolii, I., Hasan, A., \& Kandowangko, N. (2015). Pengaruh Strategi Pembelajaran Inkuiri Bebas 
Dimodifikasi dan Kemampuan

Memecahkan Masalah terhadap

Keterampilan Proses Sains

Mahasiswa Pada Praktikum

Fisiologi Tumbuhan. Pancaran Pendidikan, 4(3), 191-200.

Damopolii, I., \& Nunaki, J. H. (2016).

Pengembangan Media Pembelajaran Komik IPA Terpadu Materi Sistem Pencernaan pada Manusia. Pancaran Pendidikan, 5(3), 61-70.

Damopolii, I., Nunaki, J. H., \& Supriyadi, G. (2018). Effect of Problem Solving Learning Model on Students Achievement. Journal of Educational Research and Evaluation, 2(1).

Günter, T., \& Alpat, S. K. (2017). The Effects of Problem-based Learning (PBL) on the Academic Achievement of Students Studying 'Electrochemistry'. Chemistry Education Research and Practice, 18(1), 78-98.

Günter, T., Akkuzu, N., \& Alpat, Ş. (2017). Understanding 'Green Chemistry' and 'Sustainability': An Example of Problem-based Learning (PBL). Research in Science \& Technological Education, 35(4), 500-200.

Hallinger, P., \& Lu, J. (2011). Assessing the Instructional Effectiveness of Problem-based Management Education in Thailand: A Longitudinal Evaluation. Management Learning, 42(3), 279299. doi:https://doi.org/10.1177/135 0507610388596

Irawan, P., Susanna, \& Hamid, T. (2017). Perbedaan Hasil Belajar Melalui Model Problem Based Learning dan Direct Instruction Siswa Kelas X
MAN Suak Timah Kabupaten Aceh Barat. Jurnal Ilmiah Mahasiswa (JIM) Pendidikan Fisika, 2(1), 114121.

Jansson, S., Söderström, H., Andersson, P. L., \& Nording, M. L. (2015). Implementation of Problem-Based Learning in Environmental Chemistry. Journal of Chemical Education, 92(12), 2080-2086.

Kinaseh, Subekti, N., \& Pribadi, T. A. (2015). Pengaruh Model Problem Based Learning dengan Media Animasi Flash terhadap Hasil Belajar dan Aktivitas Siswa. Unnes Journal of Biology Education, 4(3), 317-321.

Kono, R., Mamu, H. D., \& Tangge, L. N. (2016). Pengaruh Model Problem Based Learning (PBL) terhadap Pemahaman Konsep Biologi dan Keterampilan Berpikir Kritis Siswa Tentang Ekosistem dan Lingkungan Di Kelas X SMA Negeri 1 Sigi. Jurnal Sains dan Teknologi Tadulako, 5(1), 28-38.

Kusumaningtias, A., Zubaidah, S., \& Indriwati, S. E. (2013). Pengaruh Problem Based Learning Dipadu Strategi Numbered Heads Together Terhadap Kemampuan Metakognitif, Berpikir Kritis, dan Kognitif Biologi. Jurnal Penelitian Kependidikan, 23(1), 33-47.

Major, C. H., \& Palmer, B. (2001). Assessing the Effectiveness of Problem-Based Learning in Higher Education: Lessons from the Literature. Academic Exchange Quarterly, 5(1). Dikutip 13 Februari 2017 dari http://www.rapidintellect.com/AEQ web/mop4spr01.htm 
Munir, M. K., \& Damopolii, I., (2018). Pengaruh Model Pembelajaran Make a Match terhadap Hasil Belajar Siswa Di Kelas VII SMP Yapis Manokwari. KEGURU: Jurnal Ilmu Pendidikan Dasar, 2(1), 120-129.

Riyanto, Y. (2010). Paradigma Baru Pembelajaran: Sebagai Referensi Bagi Pendidik dalam Implementasi Pembelajaran yang Efektif dan Berkualitas. Jakarta: Prenada Media Group.

Rusman.

(2012).

Model-model

Pembelajaran. Jakarta: PT. Raja Grafindo Persada.

Sari, A. N., \& Harahap, N. (2015). Pengaruh Model Pembelajaran Berbasis Masalah (Problem Based Learning) Terhadap Hasil Belajar Dan Keterampilan Proses Sains Siswa pada Materi Sistem Reproduksi Manusia Di Kelas XI-PMS SMA Negeri 1 Binjai Tahun Pembelajaran 2014/2015. JURNAL PELITA PENDIDIKAN, 3(4), 29-39.

Scott, K. S. (2014). A Multilevel Analysis of Problem-Based Learning Design Characteristics. Interdisciplinary Journal of Problem-Based Learning, 8(2). doi:htps://doi.org/ 10.7771/1541-5015.1420

Slameto. (2013). Belajar dan Faktor-faktor yang Mempengaruhi. Jakarta: Rineka Cipta.

Sugiyono. (2015). Metode Penelitian Pendidikan Pendekatan Kuantitatif, Kualitatif, dan $R$ \& D. Bandung: Alfabeta.

Taşoğlu, A. K., \& Bakaç, M. (2014). The Effect of Problem Based Learning Approach on Conceptual Understanding in Teaching of
Magnetism Topics. Eurasian Journal of Physics and Chemistry Education, 6(2), 110-122.

Wahyudi, A., Marjono, \& Harlita. (2015). Pengaruh Problem Based Learning terhadap Keterampilan Proses Sains dan Hasil Belajar Biologi Siswa Kelas X SMA Negeri Jumapolo Tahun Pelajaran 2014/2013. BIOPEDAGOGI, 4(1), 5-11.

Wijnen, M., Loyens, S. M., Smeets, G., Kroeze, M. J., \& Van Der Moles, T. (2017). Students' and Teachers' Experiences With the Implementation of Problem-Based Learning at a University Law School. Interdisciplinary Journal of Problem-Based Learning, 11(2).

Yu, B., Chan, P., Chan, S. F., \& Chang, J. (2005). Exploring The Preference in Learning Approach Among The Hong Kong University Students: Case Study, Problem-Based Or Traditional Textbook Question. Developments in Business Simulations and Experiential Learning, 32, 331-336.

Yusuf, M., \& Pujiastutik, H. (2017). Improvement of Biology Learning Results Using the Problem Based Learning Model with Environmental Media. Proceeding Biology Education Conference, 14, hal. 490493. 